\title{
PEMBERIAN KREDIT DENGAN JAMINAN FIDUSIA PADA PT BANK MAYA PADA INTERNASIONAL CABANG DENPASAR PADA MASA COVID-19
}

\author{
Kadek Della Ayu Saputri, I Nyoman Putu Budiartha, Desak Gde Dwi Arini \\ Fakultas Hukum Universitas Warmadewa, Denpasar-Bali, Indonesia \\ dsaputri64@gmail.com, budiarthaputu59@gmail.com, rinidesak1966@gmail.com
}

\begin{abstract}
Abstrak
Fidusia merupakan salah satu jaminan yang efisien bagi masyarakat yang memerlukan dana di tengah pandemi Covid-19 ini seperti yang diketahui dampak dari adanya pandemi ini terlihat pada sektor perekonomian di Indonesia Bank sebagai lembaga perantara yang efektif sebagai penyalur dana untuk kegiatan pembiayaan yang produktif yang akan mendorong pertumbuhan ekonomi itu sendiri Dalam penelitian ini membahas mengenai bagaimana PT Bank Mayapada Internasional Cabang Denpasar memberikan kebijakan di tengah pandemi seperti ini kemudian mengenai pelaksanaan pemberian kredit dengan jaminan fidusia pada masa Covid-19 serta mengenai penyelesaian wanprestasi terkait pemberian kredit dengan jaminan fidusia pada masa Covid-19 Tipe penelitian yang digunakan adalah penelitian hukum empiris Berdasarkan hasil penelitian disimpulkan bahwa pelaksanaan pemberian kredit di masa pandemi ini diawali dengan pengajuan permohonan restrukturisasi kemudian melakukan analisa seperti cash flow laporan keuangan terakhir rekening koran tiga bulan terakhir kondisi agunan kunjungan usaha debitur dan yang terakhir itu dibuatkan perjanjian baru Kemudian terkait penyelesaian wanprestasi dilakukan dengan cara restrukturisasi kemudian mediasi dan yang terakhir adalah dengan cara membawa jaminan tersebut ke badan lelang.
\end{abstract}

Kata Kunci: Kredit Jaminan Fidusia Covid-19 Penyelesaian Wanprestasi

\section{Abstract}

Fiduciary is one of the efficient guarantees for people who need funds in the midst of the Covid-19 pandemic as it is known that the impact of this pandemic can be seen in the economic sector in Indonesia Bank as an effective intermediary institution as a channel for funds for productive financing activities that will encourage economic growth itself In this study discusses how PT Bank Mayapada Internasional Denpasar Branch provides policies in the midst of a pandemic like this then regarding the implementation of providing credit with fiduciary guarantees during the Covid-19 period and regarding the settlement of defaults related to providing credit with fiduciary guarantees during the Covid-19 period. 19 The type of research used is empirical legal research. Based on the results of the study, it is concluded that the implementation of credit distribution during this pandemic begins with submitting a restructuring application then performs analysis such as cash flow in the last financial statements. ir the checking account for the last three months, the collateral condition for the debtor's business visit and the latest a new agreement is made. Then the settlement of default is done by restructuring then mediation and the last is by bringing the guarantee to the auction body.

Keywords: Covid-19 Fiduciary Guarantee Credit for Default Settlement

\section{PENDAHULUAN}

Seperti yang diketahui Indonesia bahkan dunia sedang berjuang menghadapi pandemi Covid-19 hal ini sangat berdampak pada seluruh sektor kehidupan masyarakat dimana ini sangat terlihat jelas pada sektor ekonomi banyak perusahaan di Indonesia mengalami kerugian yang dikarenakan omset penjualannya menurun Hal ini justru berimbas kepada tenaga kerja yang ada di Indonesia karena dengan adanya pandemi ini banyak sekali bahkan hampir sebagian besar masyarakat Indonesia mengalami Pemutusan Hubungan Kerja (PHK) secara serentak Hal itu justru membuat masyarakat berjuang untuk tetap bertahan hidup Di masa seperti saat ini jaminan fidusia adalah salah satu jaminan yang dapat memberikan peluang bagi masyarakat yang membutuhkan dana untuk bertahan hidup di tengah Pandemi Covid-19 dimana pada masa ini masyarakat banyak mengalami Pemutusan Hubungan Kerja (PHK) dari perusahaan tempatnya bekerja. 
PT Bank Mayapada Internasional Cabang Denpasar dalam hal pelaksanaan kredit dengan jaminan Fidusia yaitu dalam pelaksanaannya perjanjian kredit dengan jaminan fidusia dilakukan dengan perjanjian yang diikatkan dengan akta jaminan fidusia Dalam hal ini pada saat dunia sedang mengalami pelemahan ekonomi sehingga peranan bank sebagai salah satu lembaga perantara yang efektif sebagai penyalur dana untuk kegiatan pembiayaan yang produktif yang akan mendorong pertumbuhan ekonomi itu sendiri Hal ini diwujudkan dalam kegiatan menghimpun dana dari masyarakat dalam bentuk simpanan dan menyalurkannya kepada masyarakat dalam bentuk pinjaman atau pemberian kredit Untuk saat ini jaminan fidusia adalah salah satu jaminan yang dapat memberikan peluang bagi masyarakat yang membutuhkan dana di tengah Pandemi Covid-19 dimana pada masa ini masyarakat banyak mengalami Pemutusan Hubungan Kerja (PHK) dari perusahaan tempatnya bekerja.

Penelitian yang serupa dengan penelitian sekarang ini, yaitu pertama tentang analisis yuridis pelaksanaan perjanjian kredit dimasa pandemi covid 19 di Bank Bri cabang Klaten (Putri \& Pamuncak, 2021). Selanjutnya tentang analisis hukum relaksasi kreadit saat pandemi corona dengan kelonggaran kredit berdasarkan Peraturan Otoritas Jasa Keuangan Nomor 11/POJK.03/2020 (Sastradinata \& Muljono, 2020), dan terakhir tentang implikasi pandemi covid-19 terhadap pelaksanaan perjanjian kredit (Syahril, 2021).

Berdasarkan pemaparan yang sudah diuraikan diatas, penelitian baru ini bertujuan untuk mengetahui pelaksanaan pemberian kredit dengan jaminan fidusia pada PT Bank Mayapada Internasional Cabang Denpasar pada masa Covid-19 dan untuk mengetahui proses penyelesaian wanprestasi dalam pemberian kredit dengan jaminan fidusia pada PT Bank Mayapada Internasional Cabang Denpasar.

\section{METODE PENELITIAN}

Penelitian ini menggunakan metode penelitian hukum empiris. Penelitian hukum empiris yaitu suatu metode penelitian hukum yang menggunakan fakta-fakta empiris yang diambil dari perilaku manusia baik perilaku verbal yang didapat dari wawancara maupun perilaku nyata yang dilakukan melalui pengamatan langsung Penelitian empiris juga digunakan untuk mengamati hasil dari perilaku manusia yang berupa peninggalan fisik maupun arsip (Fajar \& dkk, 2010).

Pendekatan masalah yang digunakan yaitu pendekatan perundang- undangan pendekatan konseptual dan pendekatan sosiologis Sumber-sumber data yang digunakan secara primer yaitu dengan melakukan wawancara dengan PT Bank Mayapada Internasional Cabang Denpasar Sedangkan data sekunder yang digunakan seperti bahan hukum primer yaitu Undang-Undang Dasar Negara Republik Indonesia Tahun 1945 Kitab Undang-Undang Hukum Perdata Undang-Undang Nomor 7 Tahun 1992 sebagaimana diubah dengan Undang-Undang Nomor 10 Tahun 1998 tentang Perbankan UndangUndang Nomor 42 Tahun 1999 tentang Jaminan Fidusia dan bahan hukum sekunder yang didapat dengan membaca buku dan jurnal hukum yang berkaitan dengan jaminan fidusia (Marzuki, 2017).

Bahan hukum yang sudah terkumpul akan dianalisa dengan menggunakan teknik analisis kualitatif, yaitu metode yang digunakan untuk menganalisa data dengan mendeskripsikan data melalui bentuk kata dan digunakan untuk menafsirkan dan menginterpretasi data hasil lisan atau tertulis dari orang tertentu dan perilaku yang diamati (Moleong, 1991). Data yang telah dianalisis secara kualitatif dianalisis kembali secara deskriptif kualitatis dan sistematis sehingga membentuk suatu karya ilmiah.

\section{HASIL DAN PEMBAHASAN}

\section{Pelaksanaan Pemberian Kredit dengan Jaminan Fidusia Pada PT Bank Mayapada Internasional Cabang Denpasar pada Masa Covid-19}

Ditengah pandemi seperti ini seluruh bank termasuk PT Bank Mayapada Internasional Cabang Denpasar tidak mengeluarkan pinjaman dalam bentuk apapun Sehingga berdasarkan arahan dari Otoritas Jasa Keuangan maka dalam hal ini PT Bank Mayapada Internasional Cabang Denpasar memberikan beberapa kebijakan kepada debitur seperti berikut (Wawancara dengan Ibu Purnama Dewi bagian Legal PT Bank Mayapada Internasional Cabang Denpasar 23 November, 2020)

a. Penilaian kualitas kredit/pembiayaan/penyediaan dana lain hanya berdasarkan ketepatan pembayaran pokok dan atau bunga kredit.

b. Restrukturisasi dengan peningkatan kualitas kredit/pembiayaan menjadi lancar setelah direstrukturisasi Dalam hal ini dilakukan dengan penurunan suku bunga dan perpanjangan jangka waktu. 
c. Penerapan kebijakan yang mendorong stimulasi pertumbuhan ekonomi untuk debitur yang terkena dampak penyebaran Covid-19 termasuk debitur usaha mikro kecil menengah Hal ini dimaksudkan agar para debitur baik debitur umum dan debitur UMKM dapat bertahan hidup di tengah pandemi ini dan dapat meningkatkan perekonomian di Indonesia.

Mengenai pelaksanaan dalam pemberian kredit dengan jaminan fidusia pada masa Covid-19 ini berlaku bagi debitur lama yang mengajukan restrukturisasi tahapannya sebagai berikut (Wawancara dengan dengan I Gusti Ayu Candra Dewi Parwati bagian Administrasi Kredit di PT Bank Mayapada Internasional Denpasar, 7 Desember 2020)

a. Membuat surat permohonan restrukturisasi dari debitur yang dimana berisikan kemampuan debitur untuk membayar angsuran setiap bulannya dan berisi mengenai kondisi debitur saat ini yang mengakibatkan debitur mengajukan permohonan restrukturisasi.

b. Proyeksi cash flow cash flow adalah perlajuan uang masuk (cash inflow) maupun uang keluar (cash outflow) Dalam hal ini PT Bank Mayapada Internasional Cabang Denpasar melakukan analisa terkait pergerakan uang debitur yang mengajukan restrukturisasi.

c. Menganalisa laporan keuangan terakhir si debitur diperlukan untuk mempermudah kelayakan apakah debitur tersebut layak untuk diberikan restrukturisasi Dalam hal ini pihak bank akan melakukan pengecekan laporan keuangan apakah debitur tersebut benar sedang mengalami penurunan pendapatan atau omset.

d. Menganalisa rekening koran selama tiga bulan terakhir yang bertujuan untuk mengecek seluruh rincian data transaksi rekening debitur Hal ini untuk membuktikan bahwa alur keuangan nasabah tersebut tetap berjalan lancar namun mengalami penurunan.

e. Kondisi dan nilai agunan debitur dalam hal ini PT Bank Mayapada Internasional Cabang Denpasar akan mengecek bagaimana kondisi dari jaminan yang digunakan dan juga menganalisa apakah nilai jaminan tersebut dapat memenuhi nilai peminjaman Namun untuk menganalisa tersebut akan dilihat melalui nilai jual pasar di tahun ini.

f. Melakukan kunjungan usaha bagi debitur yang memiliki usaha Kegiatan ini dilakukan oleh bagian appraisal yang akan melihat apakah memang benar usaha debitur tersebut mengalami penurunan.

g. Tahap terakhir adalah setelah debitur memenuhi syarat sesuai dan dianggap layak untuk mendapatkan restrukturisasi maka pihak bank akan membuatkan kembali perjanjian kredit baru Dimana perjanjian tersebut berisi mengenai suku bunga jangka waktu biaya angsuran dan sebagainya sama seperti membuat perjanjian di awal.

Pelaksanaan pemberian kredit dengan jaminan fidusia yang diberikan oleh PT Bank Internasional Cabang Denpasar di masa pandemi Covid-19 diawali dengan membuat surat permohonan restrukturisasi yang berisi kemampuan debitur membayar dan kondisi yang mengakibatkan debitur mengajukan permohonan Kemudian pihak bank akan melakukan berbagai analisa seperti menganalisa pendapatan masuk dan keluar debitur laporan keuangan terakhir debitur rekening koran dan yang terakhir menganalisa mengenai kondisi dan nilai jaminan yang digunakan debitur Setelah itu PT Bank Mayapada Internasional Cabang Denpasar akan melakukan kunjungan bagi debitur yang memiliki usaha Selanjutnya setelah semua syarat telah dipenuhi dan dianggap layak oleh pihak bank maka akan dibuatkan kembali perjanjian kredit sama seperti di awal.

\section{Penyelesaian Wanprestasi yang Timbul dalam Pemberian Kredit dengan Jaminan Fidusia}

Untuk dapat mengatakan bahwa seorang debitur melakukan perbuatan wanprestasi dalam suatu perjanjian maka pihak bank harus dapat membuktikan bahwa debitur tersebut tidak dapat melaksanakan kewajibannya atau prestasi. Menurut Ridwan, (1997), yang dimaksud dengan Wanprestasi adalah kelalaian suatu pihak dalam memenuhi kewajibannya terhadap pihak lain yang seharusnya diutamakan berdasarkan perikatan yang telah dibuat.

Wanprestasi atau tidak dipenuhinya janji dapat terjadi baik karena sengaja maupun tidak sengaja Pihak yang tidak sengaja melakukan wanprestasi ini dapat terjadi karena memang tidak mampu untuk memenuhi prestasi tersebut atau juga terpaksa untuk tidak melakukan prestasi tersebut (Salim, 2008).

Perilaku wanprestasi menimbulkan konsekuensi bagi pihak yang dirugikan karena akan pihak yang merasa dirugikan dalam hal ini pihak bank akan menuntut pihak yang melakukan wanprestasi dalam hal ini debitur untuk memberikan ganti rugi Sehingga secara hukum diharapkan bersikap adil agar tidak ada satupun pihak yang merasa dirugikan terhadap tindakan tersebut. 
Berdasarkan hasil penelitian pada tanggal 27 November 2020 dengan Ibu Purnama Dewi bagian Legal pada PT Bank Mayapada Internasional Cabang Denpasar di dalam prakteknya mengenai penyelesaian kredit yang bermasalah, umumnya dilakukan dengan dua cara, yakni

1. Penyelesaian Kredit Bermasalah melalui Jalur Non-Litigasi

Penyelesaian sengketa melalui jalur non litigasi adalah penyelesaian sengketa yang dilakukan diluar pengadilan sesuai dengan kesepakatan yang dilakukan oleh para pihak dengan mengesampingkan penyelesaian sengketa melalui jalur litigasi atau pengadilan. Berdasarkan Undang-Undang Nomor 30 Tahun 1999 tentang Arbitase dan Alternatif Penyelesaian Sengketa mengenai penyelesaian sengketa di luar pengadilan dapat dilakukan dengan cara sebagai berikut.

a. Konsultasi tidak diatur jelas dalam Undang-Undang Nomor 30 Tahun 1999 tentang Arbitrase dan Alternatif Penyelesaian Sengketa tetapi dalam rumusan Black s Law Dictionary adalah suatu tindakan yang bersifat personal antara suatu pihak tertentu dengan pihak lain yang merupakan pihak konsultan dimana pihak konsultan memberikan pendapatnya kepada klien sesuai dengan keperluan dan kebutuhan kliennya.

b. Negosiasi adalah suatu proses tawar-menawar atau upaya untuk mencapai kesepakatan dengan pihak lain melalui proses interaksi komunikasi yang dinamis dengan dengan tujuan untuk mendapatkan penyelesaian atau jalan keluar atas suatu masalah yang sedang berlangsung (Ikatan Bankir, 2011).

c. Mediasi Menurut John W Head mediasi adalah suatu prosedur penegakan dimana seseorang bertindak sebagai kendaraan untuk berkomunikasi antara para pihak sehingga pandangan mereka yang ada atas sengketa tersebut dapat dipahami dan mungkin didamaikan tetapi tanggung jawab utama tercapainya suatu perdamaian tetap berada di tangan para pihak sendiri-sendiri (Soemartono, 2006).

d. Konsiliasi adalah penyelesaian sengketa yang dilakukan diluar pengadilan yang dibantu oleh konsiliator dengan memberikan solusi mengenai pemecahan masalah kepada para pihak.

e. Arbitrase berdasarkan Pasal 1 angka 1 Undang-Undang Nomor 30 Tahun 1999 tentang Arbitrase Dan Alternatif Penyelesaian Sengketa menentukan bahwa Arbitrase adalah cara penyelesaian suatu sengketa perdata diluar peradilan umum yang didasarkan pada perjanjian arbitrase yang dibuat secara tertulis oleh para pihak yang bersengketa.

2. Penyelesaian Sengketa Kredit Bermasalah melalui Jalur Litigasi

Penyelesaian sengketa kredit dengan jalur litigasi adalah penyelesaian masalah hukum melalui jalur pengadilan dengan mengajukan gugatan Penyelesaian secara litigasi terhadap debitur wanprestasi dapat dilakukan dengan cara sebagai berikut.

a) Mengajukan gugatan ke Pengadilan Negeri sesuai dengan ketentuan hukum acara perdata atau permohonan eksekusi grosse akta Dengan cara tersebut dapat dijadikan salah satu penyelesaian kredit macet yang lebih cepat dan lebih mudah dibandingkan mengajukan gugatan perdata atas dasar wanprestasi Grosse Akta Pengakuan Hutang merupakan eksekusi pengecualian yang diatur pasal 224 HIR dan Pasal 258 Rbg yakni eksekusi yang dijalankan melalui penetapan pengadilan yang bersifat tetap Dengan aturan ini maka eksekusi tersebut dapat dilakukan lebih cepat dan lebih mudah (Hariyani, 2010).

b) Gugatan perdata melalui Pengadilan Negeri atas dasar wanprestasi Mengajukan gugatan perdata melalui Pengadilan Neger (PN) atas dasar wanprestasi (ingkar janji) dapat dijadikan opsi oleh Bank (kreditur) untuk menyelesaikan kredit macet Opsi ini dapat ditempuh apabila pihak bank (kreditur) tidak dapat melakukan eksekusi grosse akta melalui Pengadilan Negeri disebabkan antara lain perjanjian kreditnya tidak diiringi pembuatan grosse akta pengakuan utang yang dibuat secara notarial (Hariyani, 2010).

Proses penyelesaian wanprestasi pada PT Bank Mayapada Internasional Cabang Denpasar dilakukan dengan beberapa prosedur seprti yang diuraikan berikut ini (Wawancara dengan Made Eli Restuawan bagian Administrasi Kredit pada PT Bank Mayapada Internasional Cabang Denpasar 17 Desember 2020).

a. Pertama PT Bank Mayapada Internasional Cabang Denpasar akan memberikan solusi terkait debitur yang memiliki kredit macet Dimana mengenai solusi tersebut sudah dijelaskan pada bab sebelumnya yaitu dengan mengajukan restrukturisasi sehingga diharapkan dengan adanya 
keringanan yang diberikan oleh pihak bank debitur yang mengalami kredit macet dapat menjadi lancar setelah mengajukan permohonan tersebut.

b. Kedua apabila dengan restrukturisasi tersebut debitur tetap tidak dapat melakukan kewajibannya maka PT Bank Mayapada Internasional Cabang Denpasar akan melakukan mediasi dengan debitur meminta dan memberikan kesempatan kepada pihak debitur untuk menjual aset yang telah dijaminkannya secara mandiri Sehingga apabila aset tersebut sudah dijual maka uang hasil penjualan tersebut akan digunakan untuk melunasi sisa kredit yang tertunggak.

c. Ketiga apabila dengan cara restrukturisasi dan mediasi debitur masih juga tidak mampu untuk melaksanakan kewajibannya maka selanjutnya PT Bank Mayapada Internasional Cabang Denpasar akan melakukan cara penagihan jaminan debitur untuk dilakukan eksekusi biasa melalui gugatan ke pengadilan Kemudian benda yang sudah di eksekusi tersebut akan dibawa ke Kantor Lelang apabila hasil dari lelang tersebut melebihi dari jumlah pinjaman debitur maka pihak bank wajib untuk mengembalikan kelebihan tersebut kepada debitur.

Penyelesaian wanprestasi yang terjadi pada PT Bank Mayapada Internasional Cabang Denpasar dilakukan beberapa tahap yang diawali dengan dimana pihak bank akan menyarankan kepada debitur yang memiliki kredit macet tersebut untuk mengajukan restrukturisasi seperti yang sudah dijelaskan sebelumnya yang diharapkan nantinya setelah mengajukan hal tersebut debitur dapat membayar kredit nya Apabila dengan restrukturisasi debitur tersebut masih tetap tidak mampu untuk membayar kreditnya maka pihak bank akan memberikan wewenang atau kesempatan kepada debitur untuk menjual secara pribadi benda yang dijadikan jaminan itu yang nantinya hasil dari penjualan tersebut akan diberikan oleh debitur kepada pihak bank untuk melunasi utangnya Kemudian apabila dengan cara tersebut debitur tidak mampu menjual jaminan nya maka pihak bank akan melakukan eksekusi terhadap benda jaminan tersebut dan membawanya ke Kantor Lelang Dan apabila hasil jual dari Badan Lelang tersebut melebihi dari jumlah sisa kredit yang dimiliki maka pihak bank wajib untuk mengembalikan berapapun sisanya kepada debitur.

\section{SIMPULAN DAN SARAN}

\section{Simpulan}

Pelaksanaan pemberian kredit dengan jaminan fidusia pada masa Covid-19 di PT Bank Mayapada Internasional Cabang Denpasar dalam pemberian kreditnya dengan jaminan fidusia kepada debitur di tengah pandemi Covid-19 memberikan beberapa kebijakan demi mendukung stimulus pertumbuhan ekonomi Kebijakan tersebut seperti penurunan suku bunga dan perpanjangan jangka waktu yang diberikan setelah mengajukan restrukturisasi Kemudian mengenai pelaksanaan pemberian kredit dengan jaminan fidusia di masa pandemi Covid-19 ini PT Bank Mayapada Internasional Cabang Denpasar memberikan beberapa persyaratan yang berbeda dengan pemberian kredit sebelumnya Dimana pelaksanaan pemberian kredit ini diawali dengan debitur membuat surat permohonan restrukturisasi yang berisi kemampuan debitur membayar dan kondisi yang mengakibatkan debitur mengajukan permohonan Kemudian pihak bank akan melakukan berbagai analisa seperti menganalisa pendapatan masuk dan keluar debitur laporan keuangan terakhir debitur rekening koran dan yang terakhir menganalisa mengenai kondisi dan nilai jaminan yang digunakan debitur. Setelah itu, PT Bank Mayapada Internasional Cabang Denpasar akan melakukan kunjungan bagi debitur yang memiliki usaha. Selanjutnya, setelah semua syarat telah dipenuhi dan dianggap layak oleh pihak bank maka akan dibuatkan kembali perjanjian kredit sama seperti di awal.

Kemudian, penyelesaian wanprestasi yang dilakukan oleh PT Bank Mayapada Internasional Cabang Denpasar yang dilakukan oleh debitur di tengah pandemi Covid-19 pertama pihak bank akan menyarankan kepada debitur untuk mengajukan restrukturisasi dengan membuat surat permohonan restrukturisasi Kemudian apabila dengan restrukturisasi debitur masih tidak mampu memenuhi kewajibannya maka cara selanjutnya adalah melakukan mediasi dimana dalam hal ini pihak bank akan terlebih dahulu memberikan wewenang dan kesempatan kepada debitur untuk dapat menjual sendiri aset yang dijaminkan kemudian hasil dari penjualan tersebut akan digunakan untuk pelunasan hutang Apabila cara mediasi tidak dapat menyelesaikan masalah tersebut maka pihak bank akan menempuh jalur hukum dimana pihak bank akan melakukan penagihan dan penyitaan terhadap barang jaminan dan kemudian akan membawanya ke badan lelang. 


\section{Saran}

Melalui penelitian ini diharapkan kepada pemerintah supaya memperhatikan lagi masyarakatnya bukan hanya mementingkan pertumbuhan ekonomi saja melainkan tetap memperhatikan kesejahteraan masyarakatnya Kemudian perlu juga dibuatkan payung hukum yang lebih kuat dan peraturan mengenai pelaksanaan pemberian pinjaman agar tetap berjalan efektif di tengah pandemi Covid-19. Selain itu, kepada perusahaan PT Bank Mayapada Internasional Cabang Denpasar diharapkan juga dapat memberikan kebijakan-kebijakan yang lebih lagi mengingat ekonomi masyarakat bahkan dunia mengalami penurunan Sehingga diharapkan bank sebagai lembaga pembiayaan dapat memenuhi kebutuhan masyarakat dan juga para UMKM Kebijakan yang dimaksud bukan hanya mengenai pelaksanaan pemberian kredit melainkan juga terkait penyelesaian masalah kredit macet. Terakhir, kepada masyarakat sebagai nasabah diharapkan dapat lebih memanfaatkan segala sesuatu nya dengan baik Walaupun pemerintah dan bank sudah menerapkan beberapa kebijakan bukan berarti nantinya masyarakat dapat menyalahgunakan kebijakan tersebut Sehingga dengan bantuan dari masyarakat juga nantinya diharapkan dapat membantu untuk mempercepat laju pertumbuhan ekonomi

\section{DAFTAR PUSTAKA}

Fajar, M., \& Dkk. (2010). Dualisme Penelitian Hukum Normatif dan Empiris. Yogyakarta: Pustaka Belajar. Hariyani, I. (2010). Resi Gudang Sebagai Jaminan Kredit \& Alat Perdagangan. Jakarta: Sinar Grafika.

Ikatan Bankir. (2011). Mengelola Kredit Secara Sehat. Jakarta: Gramedia Utama.

Marzuki, P. M. (2017). Penelitian Hukum: Metode Penelitian dan Pencarian Kebenaran. Jakarta: Penerbit Kencana.

Moleong, L. J. (1991). Metode Penelitian Kualitatif. Rosyda Karya: Bandung.

Putri, C. E. D. P., \& Pamuncak, A. W. (2021). Analisis Yuridis Pelaksanaan Perjanjian Kredit Dimasa Pandemi Covid 19 (Studi Kasus di Bank BRI Cabang Klaten). Universitas Muhammadiyah Surakarta.

Ridwan, H. A. (1997). Hukum Dalam Tanya Jawab. Jakarta: Gahlia Indonesia.

Salim, H. (2008). Pengantar Hukum Perdata Tertulis (BW). Jakarta: Sinar Grafika.

Sastradinata, D. N., \& Muljono, B. E. (2020). Analisis Hukum Relaksasi Kreadit Saat Pandemi Corona Dengan Kelonggaran Kredit Berdasarkan Peraturan Otoritas Jasa Keuangan Nomor 11/POJK.03/2020. Jurnal Sains Sosio Humaniora, 4(2).

Soemartono, G. (2006). Arbitrase dan Mediasi di Indonesia. Jakarta: PT Gramedia.

Syahril, M. A. F. (2021). Implikasi Pandemi Covid-19 Terhadap Pelaksanaan Perjanjian Kredit. OSFPreprints. 